\title{
ORIGINAL
}

\section{Mutagenicity and DNA Strand Breaking Activity of Nitrososesamol Derived from Sesamol}

\author{
Kiyomi KikugAwA, ${ }^{*}$ Kazuyuki Hiramoto, Natsuko OJimA, \\ Hiromi NI-IYAMA, and Tetsuta KATO \\ Tokyo College of Pharmacy (1432-1 Horinouchi, Hachioji-shi, Tokyo, ₹192-03)
}

\begin{abstract}
Determination was made of the mutagenicity and DNA breaking activity of nitrososesamol derived from nitrosation of sesamol in sesame oil. Nitrososesamol was found to be mutagenic toward the Salmonella typhimurium TA100 strain without metabolic activation. This compound induced DNA single strand breaks when incubated with supercoiled plasmid DNA at $\mathrm{pH} 7.4$ and $37{ }^{\circ} \mathrm{C}$. Breaking occurred due to active oxygen species generated from nitrososesamol and dissolved oxygen since it was inhibited in the absence of oxygen and in the presence of scavengers of active oxygen species. Hydroxyl radical was detected in a solution of nitrososesamol by electron spin resonance (ESR)-spin trapping. The DNA strand breaking activity of nitrososesamol was enhanced by cysteine. The breaking activity of a mixture of nitrososesamol and cysteine was found due to active oxygen species since breaking was suppressed in the absence of oxygen and in the presence of scavengers of active oxygen species. A phenoxyl radical and complex radical species were generated in a mixture of nitrososesamol and cysteine, but neither of these may contribute to breaking. Other nitrosophenols also induced DNA strand breaking in the absence and presence of cysteine via active oxygen species.
\end{abstract}

\section{Introduction}

Sesame oil, widely used as an edible oil and a solvent for injections, contains several constituents including sesamin, sesamolin, sesamol $^{1), 2)}$ and sesaminol ${ }^{3)}$. Sesamol $\left(3,4^{-}\right.$ methylenedioxyphenol), a monophenolic antioxidant produced from sesamolin during the processing of sesame oil, is readily converted into nitrososesamol by reaction with nitrite under simulated gastric conditions (Scheme-1) $)^{4}$. Nitrite is readily produced in the oral cavity by salivary reduction of nitrate taken from vegetables and introduced into stomach. ${ }^{5), 6)}$ Hence, oral intake of sesame oil can produce nitrososesamol in stomach.

This paper deals with mutagenicity and DNA breaking activity of nitrososesamol. The compound showed mutagenicity to Salmonella typhimurium TA100, and induced single strand breaks of supercoiled

\footnotetext{
* Corresponding author : Kiyomi KIKUGAWA
}

DNA. DNA breaking activity of nitrososesamol was found due to active oxygen species generated by the interaction of

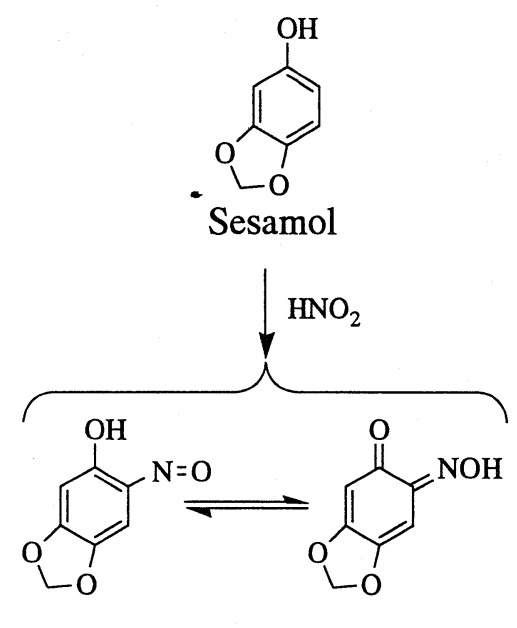

Nitrososesamol

Scheme-1 Conversion of sesamol into nitrososesamol. 
nitrososesamol with oxygen.

\section{Experimental}

\subsection{Materials}

Sesamol and $p$-nitrosophenol were obtained from Aldrich Chemical Company (Milwaukee, WI). Nitrososesamol was prepared as described previously ${ }^{4}$. 1-Nitroso2-naphthol and 1-nitroso-2-naphthol-3,6disulfonic acid disodium salt were from Wako Pure Chemical Industries (Osaka, Japan). Plasmid pBR $322 \mathrm{DNA}^{7)}\lceil 1.0 \mathrm{mg} /$ $\mathrm{mL}$ in $10 \mathrm{mM}$ Tris-HCl $(\mathrm{pH}$ 8.0), $1 \mathrm{mM}$ ethylenediaminetetraacetic acid (EDTA)] was obtained from New England Biolabs (Beverly, MA). 5,5-Dimethyl-1-pyrroline $N$-oxide (DMPO) and $N$ - $t$-butyl- $\alpha$-phenylnitrone (PBN) were obtained from Labotec Company (Tokyo, Japan) and Aldrich, respectively. Catalase (EC 1.15.1.6) from bovine liver (20000 U/mg protein) and superoxide dismutase (EC 1.15.1.1) from bovine erythrocytes (4000 U/mg protein) were the products of Sigma Chemical Company (St. Louis, MO). Purified nitrogen gas (more than 99.9998 \%) was obtained from Toyo Sanso Company (Kanagawa, Japan). Other reagents were purchased from Wako.

\subsection{Analysis}

Electron spin resonance (ESR) spectrum was obtained on an X-band JES-RE1X spectrometer (JEOL, Tokyo, Japan) with a $\mathrm{Mn}^{2+}$ marker at room temperature using a capillary tube. The instrumental conditions were: field setting at $336.0 \mathrm{mT}$, scan range of $10 \mathrm{mT}$, modulation frequency of $100 \mathrm{kHz}$, microwave power of $10 \mathrm{~mW}$ and modulation amplitude of $0.1 \mathrm{mT}$.

\subsection{Mutagenicity Test}

Mutagenicity was assayed according to the preincubation method of Yahagi et al. ${ }^{8}$ using $S$. typhimurium TA98 and TA100 strains $^{9)}$. The microsomal S9 system prepared from liver microsomes of a rat treated with phenobarbital and 5,6-benzoflavone was obtained from Wako. Nitrososesamol dissolved in $0.1 \mathrm{~mL}$ of dimethyl sulfoxide at the indicated concentration was introduced per plate. More than duplicate experiments were performed using duplicate plates for each experiment, and the mean values of the data were obtained. All the data are given after subtracting the number of spontaneously formed background $\mathrm{His}^{+}$revertant colonies/plate. The background numbers of $\mathrm{His}^{+}$revertants/plate were 27-28 for TA98 without S9 mix, 34-35 for TA98 with S9 mix, 120-134 for TA100 without S9 mix and 155171 for TA100 with S9 mix. The numbers of $\mathrm{His}^{+}$revertant colonies/plate of the positive controls were $223 / 0.1 \mu \mathrm{g} 4$-nitroquinoline $N$ oxide for TA98 without S9 mix, 1141/0.1 $\mu \mathrm{g}$ 3-amino-1,4-dimethyl- $5 H$-pyrido [4,3-b]indole $(\operatorname{Trp}-\mathrm{P}-1)$ for TA98 with $\mathrm{S} 9 \mathrm{mix}$, 949/0.1 ug 2-(2-furyl)-3-(5-nitro-2-furyl)acrylamide $(\mathrm{AF}-2)$ for TA100 without S9 $\operatorname{mix}$, and $320 / 2.5 \mu \mathrm{g}$ benzo[a]pyrene for TA100 with S9 mix.

\subsection{Strand Breaking of Supercoiled DNA}

DNA strand breaking activity of nitrososesamol was examined according to the method previously described ${ }^{10), 11)}$. A $5-\mu \mathrm{L}$ aliquot of the solution of supercoiled pBR 322 DNA in $0.1 \mathrm{M}$ phosphate buffer ( $\mathrm{pH} 7.4$ ) at the final concentration of $10 \mu \mathrm{g} / \mathrm{mL}$ was mixed with a $5 \mu \mathrm{L}$ aliquot of the solution of nitrososesamol at the final concentration of $10 \mathrm{mM}$ in $0.1 \mathrm{M}$ phosphate buffer $(\mathrm{pH} 7.4)$ containing the scavengers of active oxygen species or the metal chelators at the indicated final concentration in a plastic tube with a stopper, and the mixture was incubated at $37^{\circ} \mathrm{C}$ for $18 \mathrm{~h}$ or $45 \mathrm{~h}$. For the reaction in the absence of molecular oxygen, the mixture was purged with purified nitrogen gas for 30 min immediately after mixing, and the tube was tightly stoppered and incubated. After addition of $1 \mu \mathrm{L}$ of a $0.5 \%$ bromophenol blue/0.5 \% xylene cyanol/50 \% glycerol solution, the whole mixture was subjected to agarose gel electrophoresis. Agarose gel electrophoresis was run at $4 \mathrm{~V} / \mathrm{cm}$ for $2 \mathrm{~h}$ using a Mupid-2 submarine electrophoretic apparatus (Advance Company, Tokyo, Japan). The buffer used for the electrophoresis contained $45 \mathrm{mM}$ Tris-borate buffer $(\mathrm{pH}$ 8.3), $1.0 \mathrm{mM}$ EDTA-Na $\mathrm{Na}_{2}$ and $0.5 \mu \mathrm{g} / \mathrm{mL}$ ethidium bromide. The gel was prepared by dissolving $0.7 \%$ SeaKem $^{\mathrm{TM}} \mathrm{ME}$ agarose 
(FMC BioProducts, Rockland, ME, USA). The band was visualized by irradiation at $300 \mathrm{~nm}$.

\section{Results}

Mutagenicity of nitrososesamol was tested on S. typhimurium TA98 and TA100 strains with and without metabolic activation ${ }^{9)}$. The compound at up to $50 \mu \mathrm{g} /$ plate did not show mutagenicity on TA98 strain with and without S9 mix. In contrast, the number of $\mathrm{His}^{+}$revertant colonies increased with the dose of the compound at up to $50 \mu \mathrm{g} /$ plate on TA100 strain with and without S9 mix (Fig. -1). Sesamol, a parent compound of nitrososesamol, did not show mutagenicity on both the strains under the same conditions. Hence, nitrososesamol was mutagenic.

It is known that a supercoiled (form I) DNA is convertible into a nicked open circular form (form II) DNA and/or into a linear form (form III) DNA when its single strands are cleaved, and they can be separately detected on agarose gel electrophore$\operatorname{sis}^{10)}$. When supercoiled plasmid pBR 322 DNA was incubated with $10 \mathrm{mM}$ nitrososesamol at $\mathrm{pH} 7.4$ and $37^{\circ} \mathrm{C}$ for $45 \mathrm{~h}$, the single strands were cleaved. Thus, supercoiled form I DNA was converted into open circular form II DNA by the compound (Fig.-2, lane 2). However, time course studies of the breaking showed that the breaking was very slow, and significant breaking was de-

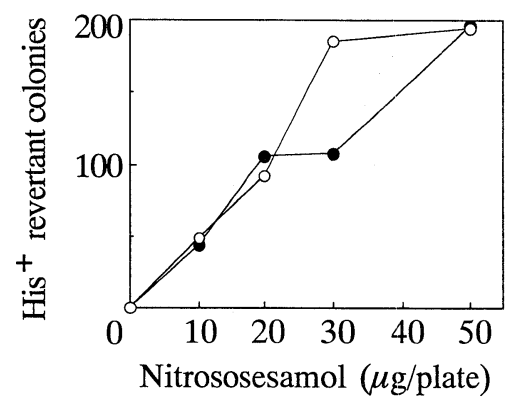

The number of $\mathrm{His}^{+}$revertant colonies/plate is expressed after background number is subtracted. The average number of two experiments using duplicate plates for each are shown.

Fig. -1 Dose response curves of mutagenicity of nitrososesamol on $S$. typhimurium TA100 with ( $\bigcirc$ ) and without (O) S9 mix. tectable only after $10 \mathrm{~h}$ (data not shown). When the reaction was conducted in the absence of oxygen by purging with nitrogen

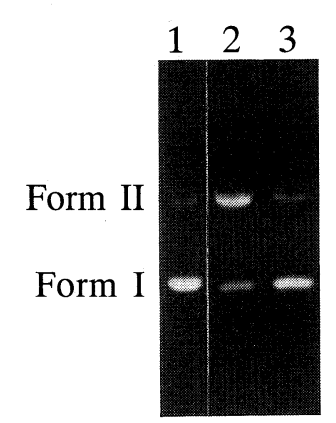

A solution of supercoiled pBR 322 DNA $(10 \mu \mathrm{g} /$ $\mathrm{mL}$ ) alone (lane 1), or a mixture of the DNA (10 $\mu \mathrm{g} / \mathrm{mL}$ ) and $10 \mathrm{mM}$ nitrososesamol (lane 2), in $0.1 \mathrm{M}$ phosphate buffer ( $\mathrm{pH}$ 7.4) was incubated at $37^{\circ} \mathrm{C}$ for $45 \mathrm{~h}$. The mixture of the DNA and nitrososesamol purged with purified nitrogen gas for 30 min was similarly incubated (lane 3 ). The mixture was subjected to agarose gel electrophoresis. The electrophoretic positions of supercoiled DNA (form I) and open circular nicked DNA (form II) are indicated.

Fig.-2 Agarose gel electrophoresis of the incubation mixture of supercoiled DNA and nitrososesamol.

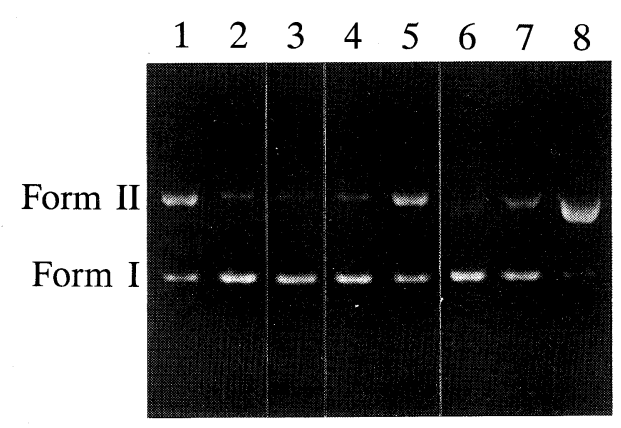

A mixture of $10 \mu \mathrm{g} / \mathrm{mL}$ supercoiled pBR 322 DNA with $10 \mathrm{mM}$ nitrososesamol in the presence of none (lane 1), $0.1 \mathrm{mg} / \mathrm{mL}$ superoxide dismutase and $0.1 \mathrm{mg} / \mathrm{mL}$ catalase (lane 2), $10 \%$ ethanol (lane 3), $50 \mathrm{mM}$ PBN (lane 4), $50 \mathrm{mM}$ DMPO (lane 5), $50 \mathrm{mM}$ EDTA (lane 6), $50 \mathrm{mM}$ DTPA (lane 7) and $50 \mathrm{mM}$ cysteine (lane 8) in $0.1 \mathrm{M}$ phosphate buffer $(\mathrm{pH} 7.4)$ was incubated at $37^{\circ} \mathrm{C}$ for $45 \mathrm{~h}$. The reaction mixture was subjected to agarose gel electrophoresis as shown in Fig. -2 .

Fig.-3 Effect of the scavengers of active oxygen species, the spin trapping agents and the metal chelating agents on the strand breaking of supercoiled DNA by nitrososesamol. 
gas, the strand breaking was prevented (Fig.-2, lane 3), indicating that the strand breaking by nitrososesamol required dissolved oxygen.

Effect of the scavengers of active oxygen species, the spin trapping agents and the metal chelating agents on DNA strand breaking by nitrososesamol at $\mathrm{pH} 7.4$ and 37 ${ }^{\circ} \mathrm{C}$ for $45 \mathrm{~h}$ was investigated (Fig. -3 ). DNA strand breaking was effectively inhibited in the presence of a mixture of superoxide dismutase and catalase, which removes both superoxide and hydrogen peroxide (lane 2). The breaking was also inhibited effectively by ethanol, which scavenges hydroxyl radical (lane 3). Spin trapping agents, PBN (lane 4) and DMPO (lane 5), were also inhibitory. Metal chelating agents, EDTA (lane 6) and diethylenetriaminepentaacetic acid (DTPA) (lane 7), which may prevent the conversion of hydrogen peroxide into hydroxyl radical by a trace amount of contaminated ferrous ion via Fenton-type reaction, or which may scavenge hydroxyl radical generated ${ }^{12)}$, were also inhibitory. These results suggest that DNA strand breaking by nitrososesamol was due to active oxygen species, superoxide, hydrogen peroxide and hydroxyl radical. Unexpectedly, cysteine (lane 8) was not inhibitory but stimulatory for DNA breaking by nitroso- sesamol.

An ESR-spin trapping technique was employed for detection of active oxygen radicals in an aqueous solution of nitrososesamol. When nitrososesamol was incubated with DMPO at $\mathrm{pH} 7.4$ for $1 \mathrm{~h}, 4$ lines of ESR signals with a relative intensity of $1: 2$ : $2: 1$ and hyperfine splitting constants (hf$\mathrm{sc)}$ of $a_{\mathrm{N}}=a_{\mathrm{H}}=1.49 \mathrm{mT}$, characteristic to those of DMPO-OH adduct ${ }^{13), 14)}$, appeared (Fig. -4, A). The intensity of the signals was reduced when the mixture was incubated in the presence of ethanol (Fig. -4, B), indicating that hydroxyl radical was trapped by ethanol. Incubation of nitrososesamol with DMPO for longer period did not give the ESR signals probably owing to the instability of the adduct under the conditions.

It is interesting to note that cysteine enhanced DNA strand breaking activity of nitrososesamol (Fig. -3). Other amino acids containing no thiol group did not show the enhancing effect. The enhancement by cysteine was clearly demonstrated when supercoiled DNA was incubated with $10 \mathrm{mM}$ nitrososesamol and $50 \mathrm{mM}$ cysteine at $\mathrm{pH} 7.4$ and $37^{\circ} \mathrm{C}$ for the shorter period of $18 \mathrm{~h}$ (Fig. -5 , lane 1). The strand breaking induced by nitrososesamol and cysteine was slightly inhibited in the absence of dissolved oxygen

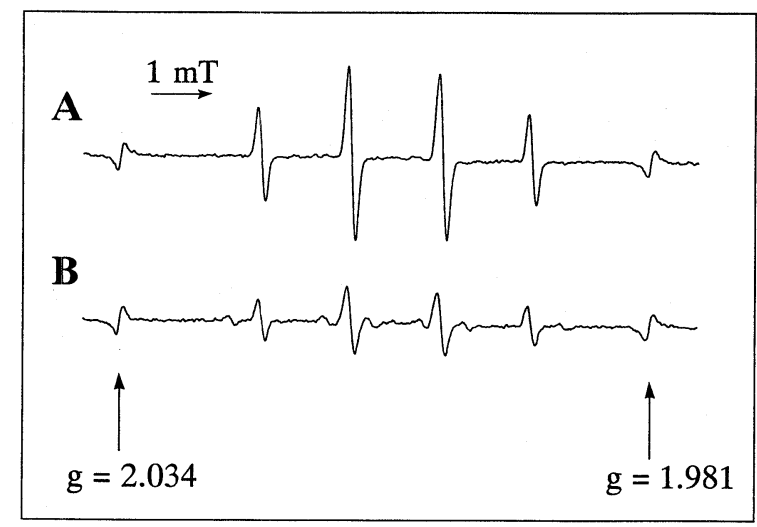

A mixture of $10 \mathrm{mM}$ nitrososesamol and $0.8 \mathrm{M}$ DMPO in $0.1 \mathrm{M}$ phosphate buffer ( $\mathrm{pH} 7.4$ ) in the absence (A) and presence (B) of 10 $\%$ ethanol was incubated at room temperature for $1 \mathrm{~h}$ and the spectrum was recorded. The right and left side signals are those of $\mathrm{Mn}^{2+}$. Receiver gain was set at 1000 .

Fig. -4 ESR spectra of the mixture of nitrososesamol and DMPO. 
(lane 2). The strand breaking was suppressed in the presence of superoxide dismutase and catalase (lane 3), ethanol (lane 4), slightly by PBN (lane 5), and DMPO

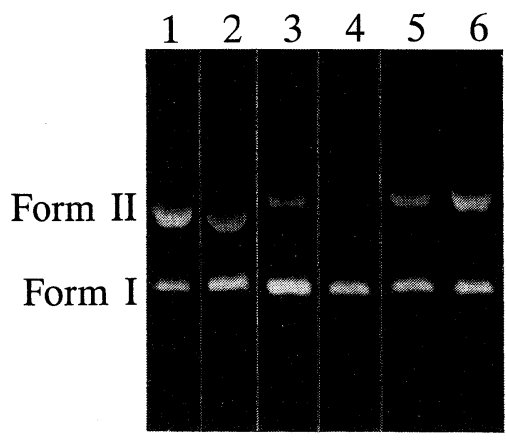

A mixture of $10 \mu \mathrm{g} / \mathrm{mL}$ supercoiled pBR 322 DNA with $10 \mathrm{mM}$ nitrososesamol and $50 \mathrm{mM}$ cysteine in the presence of none (lane 1), in the absence of dissolved oxygen (lane 2), and in the presence of $0.1 \mathrm{mg} / \mathrm{mL}$ superoxide dismutase and $0.1 \mathrm{mg} / \mathrm{mL}$ catalase (lane 3), $10 \%$ ethanol (lane 4), $50 \mathrm{mM}$ PBN (lane 5) or $50 \mathrm{mM}$ DMPO (lane 6), in $0.1 \mathrm{M}$ phosphate buffer ( $\mathrm{pH} 7.4$ ) was incubated at $37{ }^{\circ} \mathrm{C}$ for $18 \mathrm{~h}$. The mixture was subjected to agarose gel electrophoresis as shown in Fig.-2. A solution of $50 \mathrm{mM}$ cysteine in the buffer did not induce any significant strand breaks under the same conditions.

Fig. -5 Effect of the scavengers of active oxygen species, the metal chelating agent and the spin trapping agents on the strand breaking of supercoiled DNA by nitrososesamol and cysteine. (lane 6). Because $50 \mathrm{mM}$ cysteine alone did not induce any significant DNA strand breaks under the same conditions, it is likely that the enhanced breaking by cysteine is due to the enhanced generation of active oxygen species from nitrososesamol.

An ESR-spin trapping technique was employed for detection of active oxygen radicals in the mixture of nitrososesamol and cysteine. When the mixture was incubated with DMPO at $\mathrm{pH} 7.4$ only for 5 min, 4 lines of ESR signals with a relative intensity of $1: 2: 2: 1$ and hfsc of $a_{\mathrm{N}}=a_{\mathrm{H}}=1.49 \mathrm{mT}$, characteristic to those of DMPO-OH adduct ${ }^{13), 14)}$, appeared (Fig.-6). The ESR signals were not detectable after incubation for the longer period, indicating that the adduct was unstable under the conditions. Direct ESR measurement of the mixture of nitrososesamol and cysteine incubated at $\mathrm{pH} 7.4$ revealed two kinds of ESR signals : multi-line signals after $2 \mathrm{~h}$ incubation and a single line signal after $20 \mathrm{~h}$ incubation (Fig.-7, A). The multi-line signals were detectable but the single line signal was not, when the mixture was incubated in the absence of dissolved oxygen (Fig.-7, B). The result indicates that the radical species with the multi-line signals were generated by the interaction of nitrososesamol and cysteine in the absence of oxygen but the radical

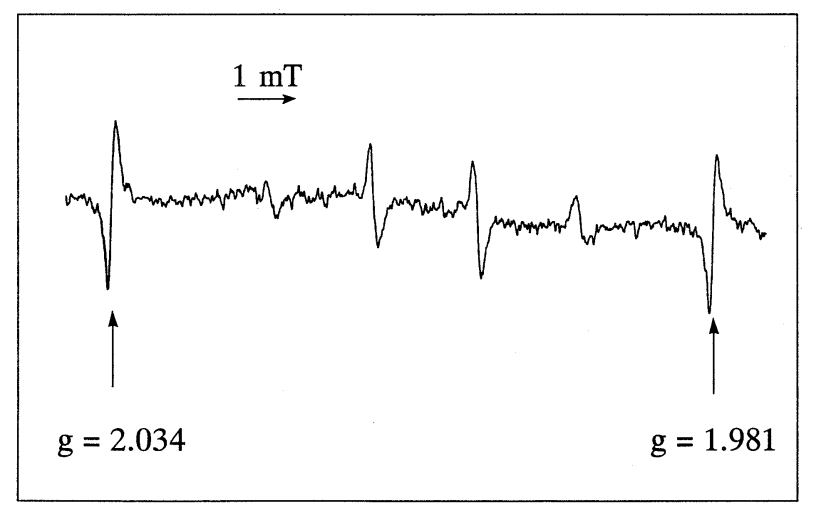

A mixture of $10 \mathrm{mM}$ nitrososesamol/50 $\mathrm{mM}$ cysteine and $50 \mathrm{mM}$ DMPO in $0.1 \mathrm{M}$ phosphate buffer ( $\mathrm{pH} 7.4$ ) was incubated at room temperature for $5 \mathrm{~min}$ and the spectrum was recorded. The right and left side signals are those of $\mathrm{Mn}^{2+}$. Receiver gain was set at 5000 .

Fig. -6 ESR spectrum of the mixture of nitrososesamol/cysteine and DMPO. 


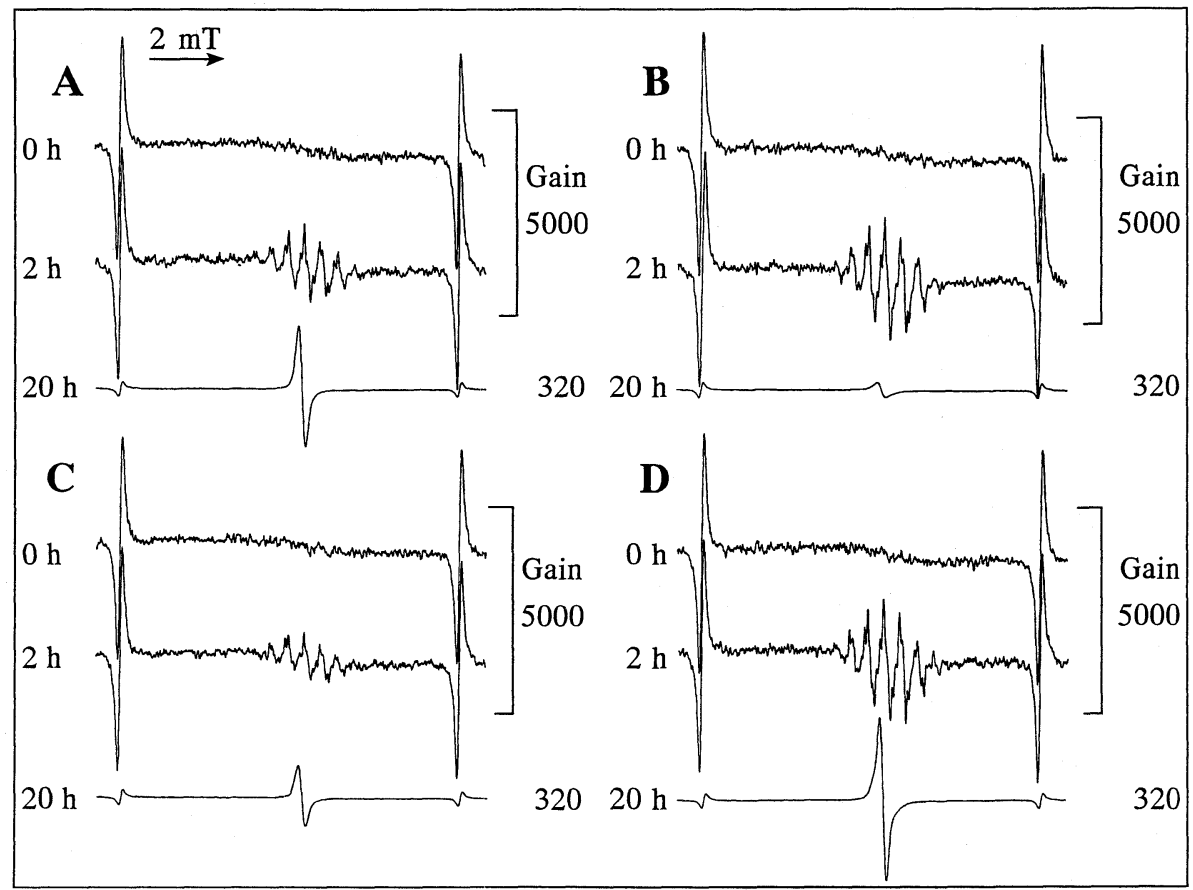

A mixture of $10 \mathrm{mM}$ nitrososesamol/50 $\mathrm{mM}$ cysteine in $0.1 \mathrm{M}$ phosphate buffer $(\mathrm{pH} 7.4)$ in the presence of none (A), in the absence of dissolved oxygen (B) or in the presence of $0.1 \mathrm{mg} / \mathrm{mL}$ superoxide dismutase and $0.1 \mathrm{mg} / \mathrm{mL}$ catalase (C) and $10 \%$ ethanol (D) was incubated at $37^{\circ} \mathrm{C}$ for the indicated period, and the spectrum was recorded. The g-values of the signals of $\mathrm{Mn}^{2+}$ marker seen in left and right sides of each ESR spectrum are 2.034 and 1.981, respectively. Receiver gain was set as indicated.

Fig. -7 ESR spectra of the mixture of nitrososesamol/cysteine.

species with the single line signal was generated by the interaction of nitrososesamol, cysteine and oxygen. Generation of both the multi-line signals and the single line signal was not affected in the presence of a mixture of superoxide dismutase and catalase (Fig. -7, C) or ethanol (Fig.-7, D), indicating that these signals were not generated by the interaction with active oxygen species. The multi-line signals were consistent with the computer-simulated ESR spectrum (Fig.-8, A) of a phenoxyl radical ${ }^{15}$ ) shown in Fig. -8, B, suggesting the formation of the phenoxyl radical by interaction of nitrososesamol with cysteine. The single line signal may be the complex radical species formed by the interaction of nitrososesamol, cysteine and oxygen. While these radical species were generated by the interaction of nitrososesamol and cysteine, these radicals

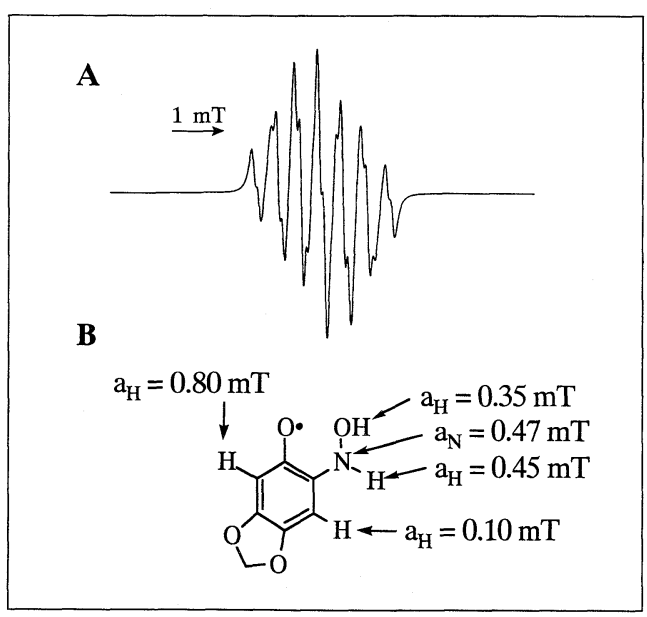

Computer-simulated ESR spectrum of a phenoxyl radical that may be generated from nitrososesamol with hfsc indicated was obtained.

Fig.-8 Computer-simulated ESR spectrum (A) of a phenoxyl radical (B). 
may not be involved in DNA strand breaking by nitrososesamol and cysteine.

DNA strand breaking activity of structural analogs of nitrososesamol, $p^{-}$nitrosophenol, 1-nitroso-2-naphthol, and 1nitroso-2-naphthol-3,6-disulfonic acid, was investigated (Fig. -9 ). When supercoiled DNA was incubated with $10 \mathrm{mM} p$-nitrosophenol under the same conditions, supercoiled form I DNA was converted into open circular form II DNA (lane 2). The breaking was inhibited in the presence of a mixture of superoxide dismutase and catalase (lane 3), ethanol (lane 4), EDTA (lane 5) and DTPA (lane 6), and enhanced in the presence of cysteine (lane 7). While supercoiled DNA was incubated with $10 \mathrm{mM} \mathrm{1-}$ nitroso-2-naphthol or 1-nitroso-2-naphthol3,6-disulfonic acid, a little DNA strand breaking was observed (lanes 8 and 10), and

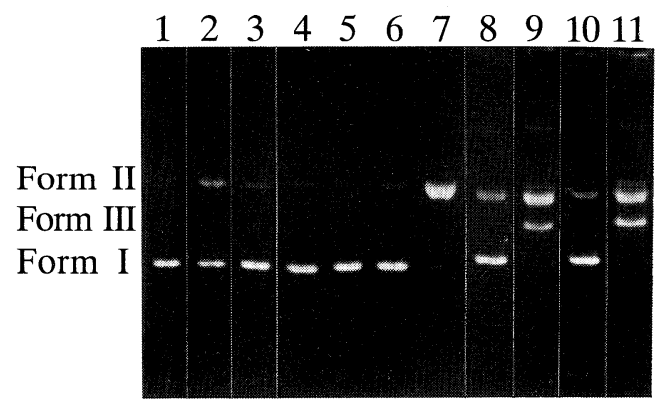

A solution of $10 \mu \mathrm{g} / \mathrm{mL}$ supercoiled pBR 322 DNA alone (lane 1), a mixture of the DNA with $10 \mathrm{mM}$ $p$-nitrosophenol in the presence of none (lane 2), $0.1 \mathrm{mg} / \mathrm{mL}$ superoxide dismutase and $0.1 \mathrm{mg} / \mathrm{mL}$ catalase (lane 3), $10 \%$ ethanol (lane 4), $50 \mathrm{mM}$ EDTA (lane 5), $50 \mathrm{mM}$ DTPA (lane 6) and $50 \mathrm{mM}$ cysteine (lane 7), a mixture of the DNA with 10 $\mathrm{mM}$ 1-nitroso-2-naphthol in the presence of none (lane 8) and $50 \mathrm{mM}$ cysteine (lane 9), or a mixture of the DNA with $10 \mathrm{mM}$ 1-nitroso-2-naphthol $-3,6$-disulfonic acid in the presence of none (lane 10 ) and $50 \mathrm{mM}$ cysteine (lane 11), in $0.1 \mathrm{M}$ phosphate buffer ( $\mathrm{pH} 7.4$ ), was incubated at $37^{\circ} \mathrm{C}$ for 45 $\mathrm{h}$. The reaction mixture was subjected to agarose gel electrophoresis. The electrophoretic positions of supercoiled DNA (form I), nicked open circular DNA (form II) and linear DNA (form III) are indicated.

Fig. -9 Strand breaking of supercoiled DNA by $p$-nitrosophenol, 1-nitroso-2-naphthol and 1-nitroso-2-naphthol-3,6-disulfonic acid. addition of cysteine to the mixtures enhanced the strand breaking (lane 9 and 11). It was found that, as well as nitrososesamol, $p$-nitrosophenol, 1-nitroso-2-naphthol and 1-nitroso-2-naphthol-3,6-disulfonic acid were active to cleave DNA single strands, and the activity appeared to be due to active oxygen species, and the activity was enhanced by cysteine.

\section{Discussion}

Nitrate taken from diet is excreted into saliva and is converted into nitrite by bacterial reduction in the oral cavity ${ }^{5), 6)}$. Nitrite may serve as an agent to produce carcinogenic compounds by reaction with their precursors under gastric conditions ${ }^{16)}$. Because there is a good correlation between nitrate intake and gastric cancer mortality in various countries ${ }^{17)}$, mutagenicity and carcinogenicity of the nitrosated compounds and the presence of their nitrosatable precursors have received much attention ${ }^{16}$. In our previous studies ${ }^{4}$, it has been shown that sesamol in sesame oil is readily nitrosated into nitrososesamol under simulated gastric conditions. In the present study, it was found that nitrososesamol was mutagenic and induced DNA strand breaks. Hence, sesamol in sesame oil could be a nitrosatable precursor that gives mutagenic nitrososesamol. Hence, sesamol and nitrososesamol may not be genotoxically safe compounds.

Nitrososesamol was mutagenic to Salmonella typhimurium TA100 strain without metabolic activation, and it induced DNA single strand breaks. The breaking was found due to active oxygen species generated from nitrososesamol and dissolved oxygen because the breaking was inhibited in the absence of oxygen and in the presence of the scavengers of active oxygen species. Hydroxyl radical was detected in the solution of nitrososesamol by an ESR-spin trapping technique. It was interesting to note that DNA strand breaking activity of nitrososesamol was enhanced by cysteine. The breaking activity of the mixture of nitrososesamol and cystcine was found due to 


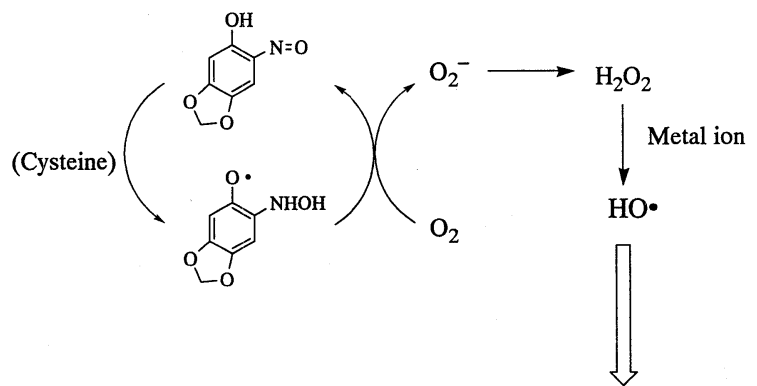

DNA strand
breaking

Scheme-2. Possible mechanism of generation of active oxygen species from nitrososesamol.

active oxygen species because the breaking was suppressed in the absence of oxygen and in the presence of the scavengers of active oxygen species. While as well as hydroxyl radical a phenoxyl radical and complex radical species were generated in the mixture of nitrososesamol and cysteine, DNA strand breaking activity was ascribable to active oxygen species. Mutagenicity of the compound may be due to active oxygen species generated.

Mechanisms of generation of active oxygen species from nitrososesamol are not known. However, the following mechanistic considerations could be made (Scheme-2). A part of nitrososesamol is reduced by its reducing ability into a (hydroxyamino)phenoxyl radical, and it is then oxidized into nitrososesamol by oxygen during which oxygen is reduced into superoxide. Superoxide is dismutated into hydrogen peroxide and then into hydroxyl radical by Fentontype reaction with an aid of a trace amount of metal ions. Initial reduction of nitrososesamol may be important for generation of active oxygen species. The fact that cysteine promoted DNA strand breaking by nitrososesamol well rationalized the importance of the reduction of nitrososesamol. Inhibition of DNA strand breaking in the absence of dissolved oxygen, by the scavengers of active oxygen species, the spin trapping agents and the metal chelating agents rationalized the above assumption.
Mechanisms of DNA strand breaking by active oxygen species have been well demonstrated ${ }^{18), 19)}$. Initially the 4 '-carbon radical of the deoxyribose moiety is formed and it is then transformed by a bimolecular reaction into the oxy-radical, and the subsequent cleavage of the $3^{\prime}-4$ ' or $4^{\prime}-5$ ' bond leads to liberation of the phosphate group from the DNA backbone. Hydroxyl radical generated from nitrososesamol and a mixture of nitrososesamol and cysteine may similarly attack the 4'-carbon of the deoxyribose moiety and induce DNA strand breaking.

As well as nitrososesamol other nitrosophenols induced DNA strand breaking via active oxygen species. Nitrosophenols were active to generate active oxygen species to induce DNA strand breaks.

(Received June 28, 1995)

\section{References}

1) P. Budowski, K.S. Markley, Chem. Rev., 48, 125 (1951).

2) P. Budowski, J. Am. Oil Chem. Soc., 41, 280 (1964).

3) Y. Fukuda, M. Namiki, Nippon Shokuhinkogaku Kaishi, 35, 552 (1988).

4) 'I'. Kurechi, K. Kikugawa, T. Kato, Chem. Pharm. Bull., 27, 2442 (1979).

5) B. Spiegelhalder, G. Eisenbrand, R. Preussmann, Food Cosmet. Toxicol., 14, 545 (1976).

6) S.R. Tannenbaum, M. Weismann, D. Fett, 
Food Cosmet. Toxicol., 14, 549 (1976).

7) F. Bolivar, R.L. Rodrigurz, P.J. Greene, M.C. Betlach, H.L. Heyneker, H.W. Boyer, Gene, 2, 95 (1977).

8) T. Yahagi, M. Nagao, Y. Seino, T. Matsushima, T. Sugimura, M. Okada, Mutation Res., 48, 121 (1977).

9) B.N. Ames, J. McCann, E. Yamasaki, Mutation Res., 31, 347 (1975).

10) P.H. Johnson, L.I. Grossman, Biochemistry, 16, 4217 (1977).

11) K. Hiramoto, K. Kido, K. Kikugawa, J. Agric. Food Chem., 42, 689 (1994).

12) K. Hiramoto, H. Johkoh, K.-I. Sako, K. Kikugawa, Free Rad. Res. Commun., 19, 323 (1993).

13) A.N. Saprin, L.H. Piette, Arch. Biochem. Biophys., 180, 480 (1977).

14) G.R. Buettner, Free Rad. Biol. Med., 3, 259 (1987).

15) “Landolt-Börnstein. Numerical Data and Functional Relationships in Science and Technology. New Series", Group II, K.-H. Hellwege, ed., Spinger-Verlag, Berlin, vol. 9 (1979) p. 29.

16) K. Kikugawa, M. Nagao, "Mutagens in Food : Detection and Prevention", H. Hayatsu, ed., CRC Press, Boca Raton, USA (1990), p. 67.

17) D.H. Fine, B.C. Challis, P. Hartman, J. Van Ryzin, "N-Nitroso Compounds : Occurrence and Biological Effects", $\mathrm{H}$. Bartsch, I.K. O’Neill, M. Castegnaro, M. Okada, W. Davis, eds., International Agency for Research on Cancer, Lyon (1982).

18) D.J. Deeble, D. Schulz, C. von Sonntag, Int.
J. Rad. Biol. Relat. Stud. Phys. Chem. Med., 49, 915 (1986).

19) D. Schulte-Frohlinde, "Oxygen Radicals in Biology and Medicine”, M.G. Simic, K.A. Taylor, J.F. Ward, C. von Sonntag, eds., Plenum, New York, (1988), p. 413.

\section{セサモールから生成するニトロソセサモー ルの変異原性と DNA 鎖切断作用}

菊川清見・平本一幸・小島奈津子・新山弘美・加藤哲太 東京薬科大学（干192-03 東京都八王子市堀ノ内 1432-1)

ごま油成分の酸化防止成分セサモールをニトロソ化し た時に生成するニトロソセサモールの変異原性とDNA 鎖切断作用を検討した。ニトロソセサモールはS Salmonella typhimurium TA100 に対して直接変異原性を 有することが明らかになった。二トロソセサモールと スーパーコイル DNA を $\mathrm{pH} 7.4,37^{\circ} \mathrm{C}$ で反応させると DNA 一本鎖切断が生じた。この切断は無酸素下および 活性酸素捕そく(捉)剂の存在下で阻害されたことより, 活性酸素によって引き起こされていることが明らかに なった。ESR スピントラップ法により，ニトロソセサ モールから発生するヒドロキシルラジカルが検出され た。ニトロソセサモールによる DNA 鎖切断はシステ インによって増強された。ニトロソセサモールとシステ インによる切断も無酸素下および活性酸素捕そく剂の存 在下で阻害されたことより, 活性酸素によって引き起こ されていることが明らかになった。ニトロソセサモール とシステインからヒドロキシルラジカルとフェノキシラ ジカルの生成が認められたが, DNA 鎖切断には関与し なかった。他のニトロソフェノール類もシステインの有 無にかかわらず活性酸素を介して DNA 鎖切断を引き 起こした。 